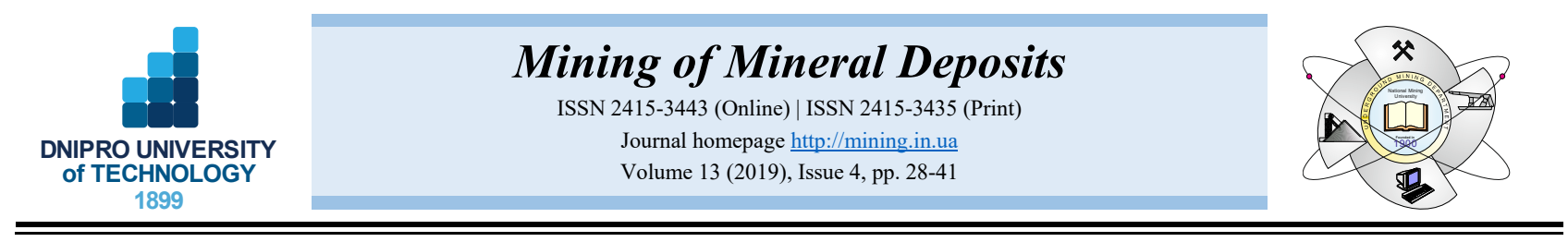

UDC 622.834:622.862.3

https://doi.org/10.33271/mining13.04.028

\title{
PHENOMENA OF STABILITY OF THE COAL SEAM ROOF WITH A YIELDING SUPPORT
}

\author{
S. Podkopaiev ${ }^{1}$, V. Gogo ${ }^{2}$, I. Yefremov ${ }^{1}$, O. Kipko ${ }^{1}$, I. Iordanov ${ }^{3}$, Yu. Simonova ${ }^{1 *}$ \\ ${ }^{1}$ Donetsk National Technical University, Pokrovsk, Ukraine \\ ${ }^{2}$ Industrial Institute of Donetsk National Technical University, Pokrovsk, Ukraine \\ ${ }^{3}$ LLC "TETZ-INVEST", Kostiantynivka, Ukraine \\ *Corresponding author: e-mail yuliia.simonova@donntu.edu.ua, tel.+380954042180
}

\begin{abstract}
Purpose. Determining the conditions and parameters for ensuring the stability of the coal seam roof with a yielding support in the area adjacent to face and behind it under the influence of dynamic loads based on the analytical and laboratory studies.

Methods. To achieve the purpose set, analytical studies have been carried out using the basic principles of the theory of elasticity and vibrations, the hypothesis of girders and the hinged-block displacement of the stratified rock stratum. Also, the laboratory studies of models from equivalent materials have been performed, in which the coal seam roof is presented in the form of a girder having a yielding support with variable rigidity from the filling material under dynamic load.

Findings. As a result of performed studies, the phenomenon has been determined that the condition for the stability of the coal seam roof is a geometric parameter that reflects moving of the girder with a yielding support, under the force impact of a falling load with a known mass and the physical-geometrical characteristics of the deformable system. It has been determined that as a result of a change in the spans length, a change in the flexural rigidity of the girder occurs, which means that the yield influence of the same supports on the stability of the coal seam roof is different. The values have been set and the relationship has been studied of the physical-mechanical characteristics of the filling mass as a yielding support.
\end{abstract}

Originality. It has been proven scientifically that the stress-strain state (SSS) of a system in which the coal seam roof is studied as a girder depends on the physical-geometrical characteristics of the system, as well as the type and place of applying the external load, in case when the law of the girder movement in time is determined.

Practical implications. The effective supporting of the undermined rock stratum in the working part of the longwall face and behind the face is achieved by placing the yielding supports in the mined-out space or by using the backfill in the mined-out space while conducting the stope operations, thus, increasing the efficiency of measures to protect the labour of miners in coal mines.

Keywords: roof stability, coal seam, stope face, phenomenon, stress-strain state, theory of elasticity and vibrations, modelling on equivalent materials

\section{INTRODUCTION}

The experience of mines that develop steeply inclined and steep coal seams shows that, with an increase in the depth of mining in a coal-bearing massif enclosing mine workings, such a natural factor occurs as the side rocks stratification, which has a significant influence on their subsequent state behind the stope face. The efficiency of mining the coal seams and the safety of mining operations in such conditions, largely depends on the way to control the roof in the stope face and safeguard of the local pre- paratory mine workings (Pivnyak, Pilov, Bondarenko, Surgai, \& Tulub, 2005; Viktorov, Iofis, \& Goncharov, 2005; Shashenko, Gapieiev, \& Solodyankin, 2009).

In conventional methods for controlling the rock pressure by complete collapsing or holding the roof on chocks, the support used in the stope face is not always able to withstand the side rocks displacement, especially in case of sudden collapse of the stratified stratum of the hinges (Viktorov, Iofis, \& Goncharov, 2005; Shashenko, Pustovoytenko, \& Sdvizhkova, 2016). Currently used methods of protecting the drifts by various

(C) 2019. S. Podkopaiev, V. Gogo, I. Yefremov, O. Kipko, I. Iordanov, Yu. Simonova. Published by the Dnipro University of Technology on behalf of Mining of Mineral Deposits. This is an Open Access article distributed under the terms of the Creative Commons Attribution License (http://creativecommons.org/licenses/by/4.0/),

which permits unrestricted reuse, distribution, and reproduction in any medium, provided the original work is properly cited. 
structures made of wood (prop stays cluster, breakerprop row) or whole coal, also do not always provide reliable protection of mine workings from dangerous rock pressure manifestations.

The suddenness of collapsing the stratified stratum, which leads to blockages of mine workings, is conditioned not only by mining-geological factors, but also miningengineering ones. The latter should include the nonconformity of the applied methods of controlling the roof in the stope face and safe-guarding the local preparatory mine workings with the specific conditions of their operation (Bondarenko, Kovalevs'ka, \& Ganushevych, 2014).

The accidents having occurred as a result of the roof rocks collapse in mine workings, as a rule, are accompanied by large financial damage and a tragic loss of human life. Therefore, the study of the nature of collapse, its impact on the state of side rocks and, based on this, the development of effective measures aimed at maintaining the mine workings in operational condition, will contribute to the creation of conditions for safe mining in deep mines.

The well-known studies analysis (Nikolin, Podkopaev, Agafonov, \& Maleev, 2005) shows that the rock pressure manifestations in mine workings depend on the combined influence of many geological factors, which should first of all include the stress state of sedimentary mine rocks surrounding the mine working and their physical-mechanical properties. Along with this, the study of the rock pressure behaviour in mine workings at great depths made it possible to set that the nature of its dangerous manifestations is determined by the specifics of forming the coal-rock massif, which cause inelastic deformation during volumetric compression, as well as the ability to deform and collapse during unloading (Nikolin, Podkopaev, Agafonov, \& Maleev, 2005).

The studies of SE Donetsk Scientific Research Coal Institute and Donetsk National Technical University have revealed that the filling mass helps to prevent the development of the stratified stratum displacements in the vicinity of the stope face and creates behind it the zones of rock stability (Zhukov, Vystorop, \& Kolchin, 1984; Zborshchik \& Podkopayev, 1992). The mechanism of filling mass interaction with sedimentary rocks is in a significant reduction of fractures formation in the rocks of the coal seam roof above the filling mass. Therefore, it significantly changes the geomechanical situation in the coal-rock massif enclosing mine workings. Thus, the use of filling of the mined-out space helps not only to preserve the side rocks stability, but also to improve the safety of miners in underground conditions.

Setting of the problem. Determining the stability conditions of the coal seam roof in the stope face while supporting the side rocks with a yielding support and its influence on the value of deformations of the roof bending caused by dynamic loads.

\section{METHODS}

In real conditions of mining the coal seams, using various methods of controlling the roof in the longwall face and protecting the drifts, the safety of mine workings is ensured by the stability of the immediate roof rocks of the coal seam, as the main load-bearing element of the underground structure.
The deformation indicators determined by the static method of load application are most often used as a parametric provision for geomechanical calculations of the side rocks stability, in case of sudden collapse of the stratified rock stratum. This can be explained by the fact that the displacement of the body marker point is the same under the action of static load, as under the action of dynamic load (Rusakov, 2003).

The analytical methods, which are the basis of elasticity theory and vibrations theory, have a fundamentally identical scheme in which between strains, stresses or their derivatives the dependences are set idealizing the properties of the objects under study Mikhlin \& Zhupiev, 1997. Then, the equations of equilibrium, movement and ensuring the stability of the modelled object are composed, taking into account the experimental data.

According to the girders hypothesis (Yakobi, 1987; Borisov, 1980; Viktorov, Iofis, \& Goncharov, 2005; Shashenko, Pustovoytenko, \& Sdvizhkova, 2016), let us assume that in the stope face, the coal seam roof is being deformed and destroyed like girders. The stability of roof outcropping in the area adjacent to the longwall face, significantly depends on the degree of its preliminary fracturing and the deflection value, when the separate blocks of the stratified rock stratum operate as hinges (Borisov, 1980; Khalymendyk \& Baryshnikov, 2018).

Based on such a model of a coal seam roof, in Figure 1, the roof rocks are represented in the form of a girder with a length $L_{g i r},(\mathrm{~m})$, height $h,(\mathrm{~m})$, and width $b$, (m), which has a fixed hinge bearing in p. $A$, and movable hinge bearing in p. $B$, the distance between them is $2 l,(\mathrm{~m})$. The $B C$ section of the girder is a cantilever, the length of which is $l,(\mathrm{~m})$. A load with mass $m,(\mathrm{~kg})$ from a certain height $H$, (m) falls onto the edge of the cantilever in p. $C$ (Fig. 1a).

\section{RESEARCH FINDINGS}

Let us study the static problem of the transverse bending of a girder. Figure 1 shows the curves of bending moments from a statically applied load with mass $m$ $(\mathrm{kg})-M_{P}(\mathrm{~N} \cdot \mathrm{m})(\mathrm{b})$; a unit force applied at the point of impact $-M_{C}(\mathrm{~N} \cdot \mathrm{m})(\mathrm{c})$; a unit force applied at the point $D-M_{D}(\mathrm{~N} \cdot \mathrm{m})(\mathrm{d})$, constructed in accordance with (Belyayev, 1985; Timoshenko \& Gere, 2002; Shakirzyanov \& Shakirzyanov, 2005; Baruh, 2015).

To determine the static girder deflection from the action of the gravitation force of the load, we use the constructed curves (Fig. 1b-1d), Vereshchagin's rule (Belyayev, 1985; Shakirzyanov \& Shakirzyanov, 2005) and determine the static deflection in p. $C$ :

$\delta_{s t}^{C}=\frac{M_{P} \cdot M_{C}}{E \cdot I}=\frac{m \cdot g \cdot l^{3}}{E \cdot I}$,

as well as in the middle of the girder span, in p. $D$ :

$\delta_{s t}^{D}=\frac{M_{P} \cdot M_{D}}{E \cdot I}=\frac{m \cdot g \cdot l^{3}}{4 \cdot E \cdot I}$,

where:

$I$-moment of inertia of the cross-section under study, $\mathrm{m}^{4}$;

$E$ - elasticity modulus, MPa. 
(a)

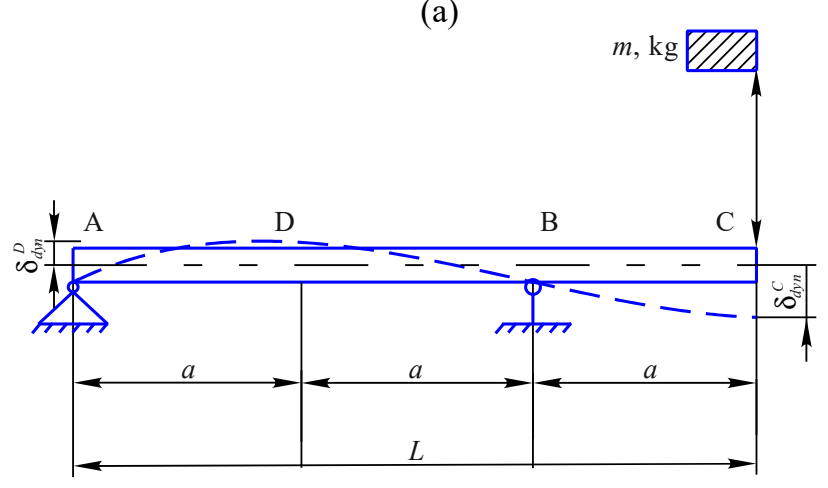

(b)

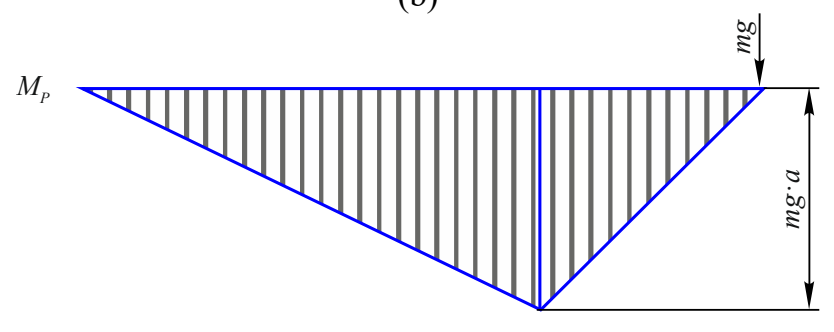

(c)

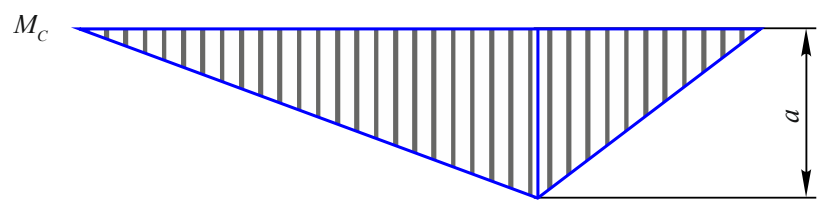

(d)

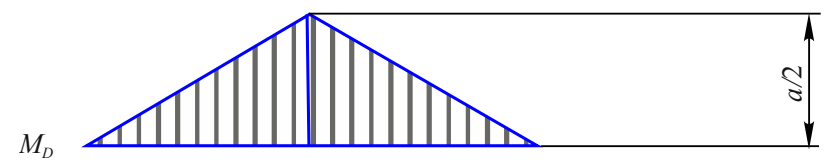

Figure 1. Scheme for determining the dynamic girder deflection at $D$ and $C$ points, with bending moments curves: (a) computational scheme; (b) MP - bending moments curve from a statically applied load with mass $\mathrm{m}$, (kg); (c) $M_{c}$ - bending moments curve from a unit force applied at the point of impact; (d) $M_{D}-$ bending moments curve from a unit force applied at the point $D ; R_{A}, R_{B}-A$ and $B$ supports reaction, respectively, $(\mathrm{H})$

It can be seen from the expression (2), that the point $D$ moves upward, and within the area adjacent to face, in $A B$ section, an arch is formed in the roof (Fig. 1a).

The dynamic deflection at $C$ and $D$ points, respectively, is equal to:

$\delta_{d y n}^{C, D}=\delta_{s t}^{C, D} \cdot k_{d y n}$,

where:

$k_{d y n}-$ dynamic coefficient.

The value of the dynamic coefficient is determined by the expression, as in (Timoshenko \& Gere, 2002; Shakirzyanov \& Shakirzyanov, 2005):

$k_{d y n}=1+\sqrt{1+\frac{2 \cdot H}{\delta_{s t}}}$,

with account of change in the height of falling load $H$, (m).
It is known (Belyayev, 1985; Tsigler, 2002; Ginsberg, 2008; Kleeppner \& Kolenkow, 2014; Baruh, 2015), that at $H=0$, the girder in the modelled system is exposed to the load instantaneous application. In this case, the value of the dynamic coefficient $k_{d y n}=2$, and the value of the deformations and stresses in the system is twice as much as under static loading. At $H>0$, as a result of the load falling onto the girder, the girder can move, that is bend in the studied system.

In the case when the girder begins to move, two active forces appear in the modelled system: one from the girder's gravitation force $Q,(\mathrm{~N})$, applied in the middle, and the second concentrated force $P,(\mathrm{~N})$, applied at the end. It is obvious that at certain points of time, under the action of maximum dynamic loads, the destruction of the girder can occur in such a system.

It can be seen from Figure 1, that in the support $B$, the reaction of the support $R_{b},(\mathrm{~N})$ will be directed towards the external force $P,(\mathrm{~N})$. The girder under the action of the force $P,(\mathrm{~N})$, tends to turn in the support $B$. However, the support $A$ prevents this, hence, the reaction in the support $R_{a},(\mathrm{~N})$ will be directed downward.

Checking the correctness of determining the supports reaction in the modelled system should be performed according to (Tsigler, 2002; Akimov, 2010), from the equation:

$\sum P_{y}=-R_{a}+R_{b}-P=-\frac{1}{2} P+\frac{3}{2} P-P=0$.

Let us determine now the maximum value of the load mass falling onto the girder, at which the destruction of the girder and the loss of the modelled system stability occur.

To do this, let us consider the sum of the force moments with respect to the support $B$ and equate it to zero, that is:

$\sum m_{b}(P)=Q \cdot 1-P \cdot 2=0$,

from which:

$P=\frac{Q}{2}$.

It follows from the expression (7), that at $P>Q / 2$ the girder is being destructed and the loss of the modelled system stability occurs.

Let us determine the natural frequency of the girder vibrations in the studied deformable system. Assume that the girder, after the load has fallen on it, carries a point mass $m,(\mathrm{~kg})$ at the end of the cantilever (Fig. 2), that is the impact effect of the load is inelastic.

The natural cyclic frequency $\omega,(1 / \mathrm{s})$ of such a system can be determined by the expression, as (Shakirzyanov \& Shakirzyanov, 2005):

$\omega=\sqrt{\frac{F}{m \cdot \delta_{11}}}$,

where:

$\delta_{11}$ - displacement of the point $B$ under the action of a unit force applied to the girder, $\mathrm{m}$;

$F$ - unit force, N. 
(a)

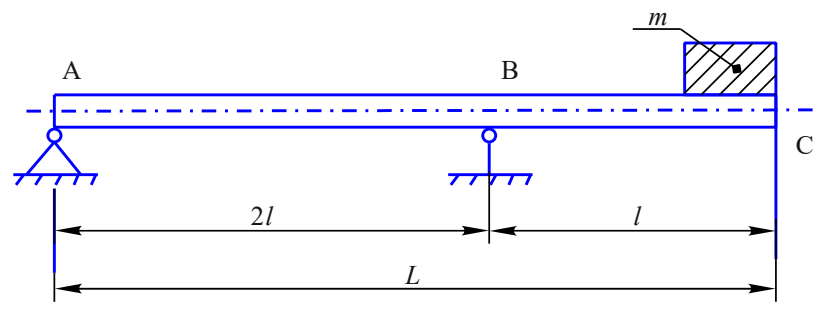

(b)

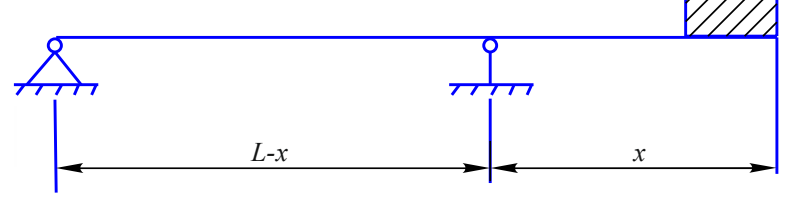

(c)

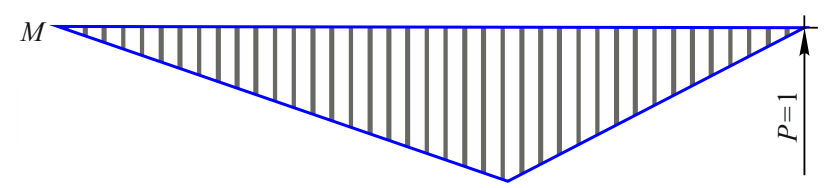

Figure 2. Scheme for determining vibrations of the load with known mass on the girder when placing the support $B$ at different distances from the support $A$ : (a) overall scheme; (b) computational scheme; (c) curve of bending moments $M$ from a unit force; $L$ - length of a girder, (m); m-load mass, (kg)

Let us consider the computational scheme of the deformable system and the curve of bending moments from a unit force (Fig. 2b, c).

In case of a random arrangement of the support $B$ :

$\delta_{11}=\frac{x^{2} \cdot L}{3 \cdot E \cdot I}$

where:

$x$ - the distance from point mass to $\operatorname{support} B, \mathrm{~m}$.

At $x=L / 3$ we get:

$\delta_{11}=\frac{L^{3}}{27 \cdot E \cdot I}$,

and then:

$\omega=\sqrt{\frac{27 \cdot E \cdot I}{m \cdot L^{3}}}$.

$$
\text { At } x=L / 2 \text { : }
$$

$\delta_{11}=\frac{L^{3}}{12 \cdot E \cdot I}$,

and then:

$\omega=\sqrt{\frac{12 \cdot E \cdot I}{m \cdot L^{3}}}$.

At $x=L / 1.5$ :

$\delta_{11}=\frac{L^{3}}{6.75 \cdot E \cdot I}$, and then:

$\omega=\sqrt{\frac{6.75 \cdot E \cdot I}{m \cdot L^{3}}}$.

Therefore, an increase in the distance from the support $B$ to the point mass $m,(\mathrm{~kg})$, leads to a decrease in the frequency of the natural vibrations of the system. But at the same time, the probability of destruction of the cantilever part of a girder (in the $B C$ section) increases. Obviously, in this case, it is necessary to use wide yielding supports or filling of the mined-out space during the stope works operations, which will help to preserve the continuity of rocks of the immediate roof.

To mitigate the action of dynamic loads and limit the value of the studied object movement in such conditions, it is recommended to use the yielding supports (Tsigler, 2002; Shakirzyanov \& Shakirzyanov, 2005; DSTU EN196-1:2007, 2007).

Suppose that in $A B$ section, the length of which is $L=2 l$, (m), the girder is loaded with a uniformly distributed load $q$, $(\mathrm{N} / \mathrm{m})$. In the middle of the span, at point $K$, we place a yielding support which has a yield $\Delta$, (m) (Fig. 3).

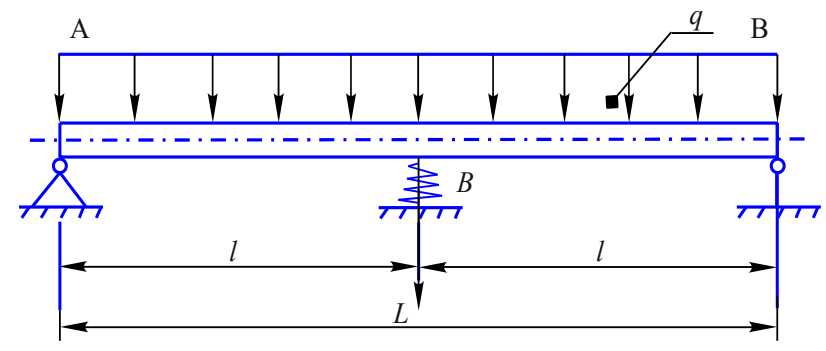

Figure 3. Computational scheme for the determining the unknown constraining force at point $K: X_{1}-u n-$ known constraining force; $K$-yielding support; $L$-length of the section $A B ; L=2 l$, (m)

According to (Belyayev, 1985; Shakirzyanov \& Shakirzyanov, 2005), the motion equation of the girder, thus, can be represented as:

$\frac{x_{1} \cdot L^{3}}{48 \cdot E \cdot I}+\Delta x_{1}-\frac{5}{384} \cdot \frac{q \cdot L^{4}}{E \cdot I}=0$,

where:

$x_{1}-$ unknown constraining force;

$\frac{5}{384} \cdot \frac{q \cdot L^{4}}{E \cdot I}-$ moving of the point $K$ of the main system from a specified load $q, \mathrm{~m}$;

$\frac{x_{1} \cdot L^{3}}{48 \cdot E \cdot I}+\Delta-$ mutual displacement of the point $K$ of the girder, in case of compressing the yielding support, $\mathrm{m}$.

From the expression (16) determine:

$x_{1}=\frac{\frac{5}{8} \cdot q \cdot L}{1+\frac{48 \cdot E \cdot I \cdot \Delta}{L^{3}}}$,

where:

$\Delta$ - yield of support, $\mathrm{m}$. 
It is obvious that under absolutely rigid support when $\Delta=0$ :

$x_{1}=\frac{5}{8} \cdot q \cdot L$,

and if $\Delta \rightarrow \infty, x_{1} \rightarrow \min$.

Into the expression (17), instead of $\Delta,(\mathrm{m})$, the actual displacement of point $K$ can be substituted.

Proceeding from the fact that any dynamic load forces the deformable system to move (Tsigler, 2002; Shakirzyanov \& Shakirzyanov, 2005), the research problem the studied object stability, under the action of dynamic loads on it, is to determine the forces and displacements generated by inertial forces and the static component of external influence when the system makes a movement.

A peculiarity of dynamic loads is that under the action of an external force on the girder, the considered system begins to vibrate. The amplitude $A,(\mathrm{~m})$ of vibrations can be determined by the expression (Strelkov, 2005; Ebrahimi, 2011; Gusev \& Novoselova, 2017):

$$
A=\sqrt{x^{2}+\frac{v^{2}}{k}},
$$

where:

$$
x \text { - girder displacement, } \mathrm{m} \text {; }
$$

$k$-natural frequency of the girder vibrations in the system with account of damping, $1 / \mathrm{s}$;

\section{$V=\sqrt{2 \cdot g \cdot H}$ - rate of the mass decrease, $\mathrm{m} / \mathrm{s}$.}

The process of natural girder vibrations in the modelled system is characterized by its quality factor $D$, the value of which depends on the logarithmic decrement $\delta$ of damping and is determined as in (Strelkov, 2005):

$D=\frac{2 \pi}{\delta}$

The physical value that determines the nature of vibrations in the system is the damping coefficient $\xi$, which is found as in (Vodop'yanov \& Belov, 2001; Kovaleva, Rutman, \& Davydova, 2013) by the expression:

$$
\xi=\frac{r}{2 \cdot m \cdot k}
$$

The modal damping coefficient $\xi$ characterizes the role of damping in a system which is exposed to vibrations with the initial displacement. It is considered (Kovaleva, Rutman \& Davydova, 2013), the lower the values of this coefficient, the longer the vibrations will last, and at $\xi \geq 1$, the system does not vibrate at all.

In the theory of vibrations, when analysing the natural vibrations of a studied object, spectral methods are often used, which are based on the replacement of the studied physical values, such as external force and rigidity, with their spectra. If the dynamic rigidity of the elastic base, a yielding support, is known, it allows to determine the density of the amplitude spectrum of movements that occur in the modelled deformable system after impact. However, not the density of the amplitude spectrum, but the phase spectrum depends on the time of the impact. However, not the density of the amplitude spec- trum, but the phase spectrum depends on the time of the impact (Strelkov, 2005, Bottega, 2006).

When studying the phase relationships between the action of an external force and the oscillator response, it was previously determined that the response of the oscillator is always lagging behind the action (Strelkov, 2005; Ebrahimi, 2011). Therefore, in the case of an external force acting on the girder, when studying the damped vibrations of a modelled system that has a yielding support, if movements in the same direction are performed simultaneously, the compared spectra should differ from each other only by a shift.

According to (Vodop'yanov \& Belov, 2001; Strelkov, 2005), between the existing characteristics that describe the vibrating properties of the considered deformable system, there is a relationship, which enables to determine the value of the phase shift $\varphi$, whose tangent $\tan \varphi$ is determined by the expression:

$\tan \varphi=\frac{x \cdot k}{v}$,

Given the fact that the rigidity of a yielding support from crushed rock with different granulometric composition can vary, the phase shift in time is proposed to be determined as $\tan \varphi$ :

$$
\tan \varphi=\frac{m_{b} g}{C} \cdot \frac{k}{V}
$$

where:

$m_{b} g$-value of the static compression force of the yielding support, $\mathrm{N}$;

$C$ - yielding support rigidity, $\mathrm{N} / \mathrm{m}$.

Let us consider the falling of a rock block with known mass $m,(\mathrm{~kg})$ onto a girder, from a certain height $H$, (m). It is obvious that the period of time $t_{p}$, (s) between the end of the external force action and the girder movement, when the girder movement reaches its greatest value, is determined by the expression presented in (Vodop'yanov \& Belov, 2001):

$t_{p}=\frac{\tan \varphi T}{2 \pi}$.

As a result of such an interaction, when it is necessary to take into account the duration of the impact, the motion equation of the girder in the modelled system can be represented as:

$$
x=A \sin (k t+\varphi)+\frac{m g}{C} .
$$

It appears that the maximum girder displacement will be at maximum compression of the yielding support, that is when the condition is met:

$\sin (k t+\varphi)=1$

and

$(k t+\varphi)=\frac{\pi}{2}$.

The duration of the impact $t_{i m p}$, (s), can be determined as in (Kil'chevskiy, 1969), by the expression: 
$t_{i m p}=\frac{\pi}{2} \cdot \sqrt{\frac{x}{g}}$,

and the time $\Delta t,(\mathrm{~s})$, during which the girder movement reaches its maximum values, taking into account (25), (26) and (27) by the expression:

$\Delta t=\frac{1}{k} \cdot\left(\frac{\pi}{2}-\varphi\right)$.

Moreover, for a girder with a yielding support of constant rigidity, for example, a spring, the value, $\Delta t$, (s), can be determined with account of (24) and (28) by the expression $\Delta t=t_{\text {imp }}+t_{p}$.

Suppose, that during the impact, the rock that has fallen onto the girder makes the girder to move and deform, as a result of which the work is performed $A_{K},(\mathrm{~J})$. Power $N$, (W), spent on movement and deformation, taking into account the time during which the girder movement reaches its maximum values, is determined by the expression (Tsigler, 2002; Akimov, 2010):

$$
N=\frac{A_{K}}{\Delta t} .
$$

Presume, that the work $A_{K}$, spent on the linear girder deformation, is accumulated in a compressible body spring, and is determined as in (Tsigler, 2002; Akimov, 2010), by the expression:

$$
A_{K}=\frac{c x^{2}}{2} \text {. }
$$

It should be noted that as a result of the falling load impact onto a girder, which is backed on a yielding support, the support is compressed. In reality, when falling the load with known mass, the maximum value of the instantaneous compression of the support $\Delta X,(\mathrm{~m})$, is equal to the sum of its static compression $m_{b} g / C$, (m) and the amplitude of harmonic vibrations $a,(\mathrm{~m})$, that is:

$\Delta x=\frac{m_{b} g}{C}+a$.

In this case, the parameter $a$, represents the possible deviation of the masses centre of the modelled deformable system from the equilibrium position.

It is known (Tsigler, 2002; Akimov, 2010), that at $t=0$ :

$x_{0}=-\frac{m_{b} g}{C}$,

and:

$$
\dot{x}=\frac{m}{m+m_{b}} \sqrt{2 g H},
$$

where:

$m_{b}-$ girder mass, $\mathrm{kg}$.

Given, that:

$a \sin \alpha=-\frac{m g}{C}$ and:

$$
a k \cos \alpha=\sqrt{2 g H} \cdot \frac{m}{m+m_{b}},
$$

after appropriate mathematical transformations, we obtain:

$a=\sqrt{\frac{m^{2} g^{2}}{C^{2}}+2 g H \frac{m^{2}}{C\left(m+m_{b}\right)}}$.

Therefore, with account of the above, the maximum value of the instantaneous compression of yielding support $\Delta X,(\mathrm{~m})$, after falling of the rock block with mass $m$, $(\mathrm{kg})$ onto a girder, is determined as:

$$
\Delta X=\frac{m_{b} g}{C}+\sqrt{\frac{m^{2} g^{2}}{C^{2}}+2 g H \frac{m^{2}}{C\left(m+m_{b}\right)}} .
$$

\section{EXPERIMENTAL MODELS}

To assess experimentally the influence of a yielding support on the value of bending deformations of the roof rocks under dynamic loads, a research has been performed on models made of equivalent materials. The experiments were conducted on a special stand, in the laboratory of rock pressure of Donetsk Scientific Research Coal Institute, when the rocks of the coal seam roof were presented in the form of a rock girder with a length $L_{g i r}=0.6 \mathrm{~m}$, thickness $h=0.02 \mathrm{~m}$ and width $B=0.04 \mathrm{~m}$. The girder mass corresponded to $m_{b}=1.4 \mathrm{~kg}$, elasticity modulus $E=8800 \mathrm{MPa}$, density $\rho=2100 \mathrm{~kg} / \mathrm{m}^{3}$. The girder was made of a sand-cement mixture, according to the recommendations (DSTU EN196-1:2007, 2007; Borshch-Komponiyets, 2013) and was loaded with an external force $P,(\mathrm{~N})$. From one side the girder was rigidly fastened in p. $A$, at a distance of $A B=2 l$ the girder was backed, in one case, on a yielding support - spring with constant rigidity $C_{s p r},(\mathrm{~N} / \mathrm{m})$, in another case, on a yielding support from crushed rock with different granulometric composition, hence, with different bulk density and void ratio.

At the final stage of research, the girder was backed on a filling mass, which was located at a minimum distance equal to $l=0.2 \mathrm{~m}$ from the support $A$.

The value of bending deformations of the roof rocks of the coal seam determines the girder stability, and the dimensionless value $y$ is the strength characteristic and depends on the main parameters of the studied system, that is:

$y=f\left(h, B, L_{g i r}, \rho, P, E\right)$.

It is known, that the ratio of external forces acting on the object and model is equal to the scale of force $K^{p}$ similarity. Consider the scale of forces according to Newton's criterion:

$K_{N}^{P}=K_{p} K_{L}^{2} K_{V}^{2}$,

by Cauchy criterion:

$K_{C}^{P}=K_{p} K_{L}^{2} K_{E}$, 
and by Froude criterion:

$K_{F}^{P}=K_{g} K_{p} K_{L}^{3}$

where:

$K_{p}, K_{V}, K_{L}, K_{E}, K_{g}$ - geometric scale of similarity, the scale of velocity, material density, elasticity and gravitation force, respectively.

When modelling by Cauchy criterion:

$K_{N}^{P}=K_{N}^{P}$,

when the indicator of forces similarity is:

$\frac{K_{N}^{P}}{K_{N}^{P}}=1$,

and the material of the model and prototype is identical, the velocities in the model will be modelled in real scale, that is $K_{V}=1$.

When modelling by Froude criterion, if:

$K_{N}^{P}=K_{F}^{P}$,

and material of the prototype is used in the model, it is not possible to agree on the Cauchy and Froude criteria.

Based on this, taking into account the Newton and Cauchy force criteria, the developed model makes possible to study the dynamics of a girder when a rock block collapses onto it. However, in this case, the girder is underloaded by gravitation forces. The systematic error assessment in the values of the forces arising during such a model development, taking into account the absolute systematic error on the model sample and natural object, can be determined by the expression:

$\Delta \varepsilon=\frac{P_{Q}}{P}\left(1-\frac{1}{K_{L}}\right)$,

where:

$P_{Q}$ - forces arising from the deadweight of the girder, $(\mathrm{N})$;

$P$ - forces arising in the roof rocks during mining operations, $(\mathrm{N})$.

The condition for the scale of mass similarity, taking into account the fact that the value of mass and force are directly proportional, is assessed by the scale factor of mass, which can be represented as:

$K_{M}=K_{p}=K_{L}^{2}$.

The process of the contacting surfaces interaction should be implemented in real timescale, that is $K_{t}=1$.

Using the $\pi$-theorem (Bridzhmen, 2001) and the significance of each of the parameters listed in (30), taking into account $(41-47)$, when $(H)$ and $(m)$ are chosen as independent dimensions, the parametric equation in a dimensionless form can be represented as:

$y=f\left(\frac{B}{L_{\text {gir }}} ; \frac{h}{L_{\text {gir }}} ; \frac{E}{\rho g L_{\text {gir }}} ; \frac{P}{E L_{\text {gir }}{ }^{2}}\right)$.

from which it follows that the linear scale is determining in the studied model.
In accordance with the above, the scale of modelling corresponded to $1: 100$, the systematic error was $\varepsilon=5 \%$.

The number of measurements $n$, which should be performed to obtain sufficiently reliable and accurate modelling results, with the indicator $\varepsilon$, was set in accordance with (Kutateladze, 1982; Bridzhmen, 2001), by the expression:

$n=\frac{V_{C}^{2} t_{s t}^{2}}{\varepsilon^{2}}$,

where:

$V_{C}-$ coefficient of variation is accepted as equal to $V_{C}=8 \%$;

$t_{s t}-$ Student criterion, $t_{s t}=1.96$;

corresponded to $n \approx 10$.

In Figure 4, there is a photo of the stand on which the experiments were conducted.

(a)

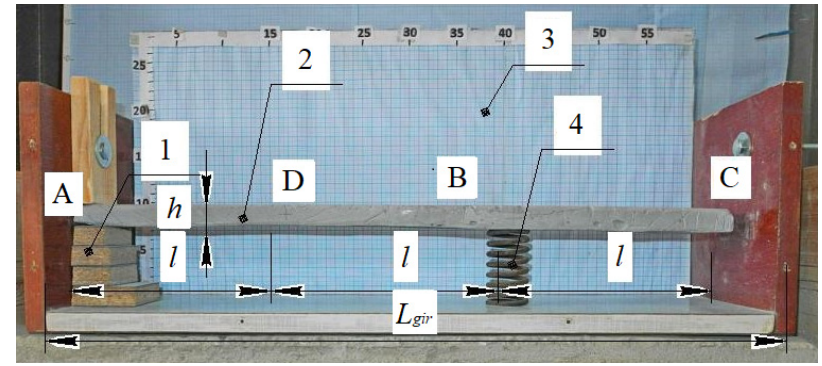

(b)

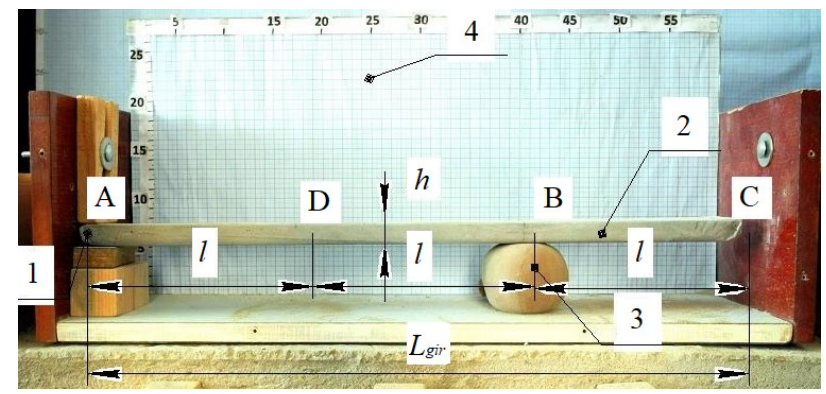

(c)

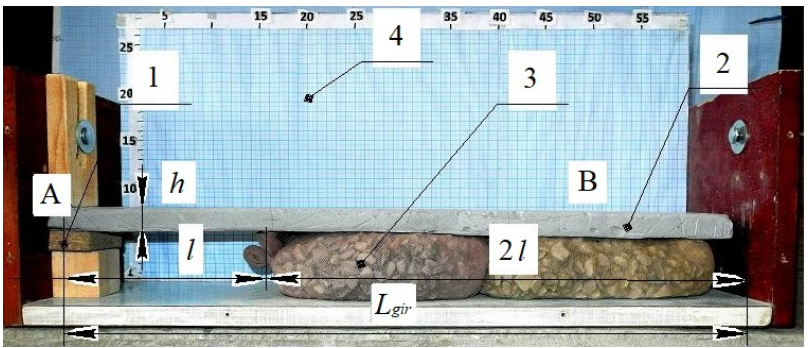

Figure 4. Photo of a stand to study the influence of dynamic loads on the stability of a coal seam roof with a yielding support: (a) of a constant rigidity; (b) from crushed rock; (c) in the form of filling mass: 1 -rigid support; 2 -girder-immediate roof; 3 -yielding support; 4-gridded stand; Lgir-length of a girder, $m$; $h$-thickness of a girder, $m ; A C=L_{\text {gir }}$; $A B=2 l ; D$ - middle of the girder span in the $A B$ section; $l=0.2 \mathrm{~m} ; \mathrm{Lgir}=0.6 \mathrm{~m}$ 
It is known (Tsigler, 2002), that the springs have their own constants, which determine their rigidity. There is a dependence which is under the Hooke's law and binds strength and rigidity, in other words, the displacement of spring from its original position. To determine the rigidity of the spring used in the models, a spring pendulum was considered (Tsigler, 2002), consisting of a metal spring and a load with mass $m,(\mathrm{~kg})$. When performing research, the spring was considered as a body of initial length $l_{s p r}$, (m), exposed to compression. In the state of equilibrium, the weight of the load located on the spring is balanced by the force of its elasticity, hence, the ratio is performed: $m g=C_{s p r} \cdot \Delta l_{s p r}$,

where:

$C_{s p r}$ - spring rigidity, $\mathrm{N} / \mathrm{m}$;

$\Delta l_{s p r}$ - value of linear compressive deformation, $\mathrm{m}$.

When determining the spring rigidity $C_{s p r},(\mathrm{~N} / \mathrm{m})$, under laboratory conditions, there were selected three loads having different masses $m,(\mathrm{~kg})$. For each load with the corresponding mass, 10 measurements have been made to determine the value of the spring compression. The experimental data for determining the spring rigidity are presented in Table 1.

Table 1. Determination of the spring rigidity $C_{s p r},(\mathrm{kN} / \mathrm{m})$

\begin{tabular}{ccccc}
\hline $\begin{array}{c}\text { Mass of the } \\
\text { load } m,(\mathrm{~kg})\end{array}$ & $\begin{array}{c}\text { Weight } \\
\text { of the load } m g,(\mathrm{~N})\end{array}$ & $\begin{array}{c}\text { Value } \\
\text { of compression } \Delta l,(\mathrm{~m})\end{array}$ & $\begin{array}{c}\text { Rigidity } \\
C_{s p r},(\mathrm{~N} / \mathrm{m})\end{array}$ & $\begin{array}{c}\text { Average value } \\
\text { of the rigidity } C_{s p r},(\mathrm{kN} / \mathrm{m})\end{array}$ \\
\hline 1.22 & 12.04 & 0.09 & 1215 & 1.2 \\
1.12 & 11.05 & 0.08 & 1210 & \\
1.1 & 10.95 & 0.08 & 1206 & \\
\hline
\end{tabular}

The granulometric composition of filling mass from crushed rock, the bulk density and void ratio of yielding support have been determined in accordance with (Havrysh \& Hrebonkina, 2004). Laboratory research data for determining the granulometric composition of crushed rock, bulk density and void ratio $M,(\%)$ of yielding support, according to variants of modelling are presented in the Tables 2 and 3.

Table 2. Granulometric composition of filling mass from crushed rock, the bulk density and void ratio of yielding support

\begin{tabular}{ccccccccc}
\hline Variants of & \multicolumn{9}{c}{ Particle sizes, $\mathrm{mm}$} & \multicolumn{2}{c}{ Bulk density } & \multicolumn{2}{c}{ Void ratio } \\
modelling & $>4.0$ & 4.0 & 3.0 & 2.0 & 1.0 & $<1.0$ & $\rho_{\text {b.d. }}\left(\mathrm{kg} / \mathrm{m}^{3}\right)$ & $M,(\%)$ \\
\hline$\# 1$ & - & - & - & - & - & $100 \%$ & 1980 & 6 \\
$\# 2$ & $3 \%$ & $17 \%$ & $21 \%$ & $24 \%$ & $19 \%$ & $16 \%$ & 1840 & 12 \\
$\# 3$ & - & $100 \%$ & - & - & - & - & 1680 & 20 \\
$\# 4$ & $100 \%$ & - & - & - & - & - & 1640 & 22 \\
\hline
\end{tabular}

Table 3. Granulometric composition, bulk density and void ratio of filling mass

\begin{tabular}{|c|c|c|c|c|c|c|c|c|}
\hline \multirow{2}{*}{$\begin{array}{l}\text { Variants of } \\
\text { modelling }\end{array}$} & \multicolumn{6}{|c|}{ Particle sizes, $\mathrm{mm}$} & \multirow{2}{*}{$\begin{array}{l}\text { Bulk density } \\
\rho_{\text {b.d. }}\left(\mathrm{kg} / \mathrm{m}^{3}\right)\end{array}$} & \multirow{2}{*}{$\begin{array}{c}\text { Void ratio } \\
M,(\%)\end{array}$} \\
\hline & $>4.0$ & 4.0 & 3.0 & 2.0 & 1.0 & $<1.0$ & & \\
\hline$\# 1$ & $3 \%$ & $17 \%$ & $21 \%$ & $24 \%$ & $19 \%$ & $16 \%$ & 1840 & 12 \\
\hline$\# 2$ & $100 \%$ & - & - & - & - & - & 1640 & 22 \\
\hline$\# 3$ & - & $100 \%$ & - & - & - & - & 1670 & 20 \\
\hline$\# 4$ & - & $50 \%$ & - & - & - & $50 \%$ & 1750 & 18 \\
\hline$\# 5$ & - & $30 \%$ & - & $30 \%$ & - & $40 \%$ & 1740 & 17 \\
\hline$\# 6$ & - & $50 \%$ & $50 \%$ & - & - & - & 1870 & 13 \\
\hline$\# 7$ & - & - & $50 \%$ & $50 \%$ & - & - & 1870 & 13 \\
\hline$\# 8$ & - & - & - & $40 \%$ & $40 \%$ & $20 \%$ & 1880 & 10 \\
\hline$\# 9$ & - & - & - & - & - & $100 \%$ & 1980 & 6 \\
\hline
\end{tabular}

To determine the conditions and parameters of roof stability, 10 models have been tested in each of the considered variants. When testing the models, the girder displacements and deformations were recorded with a digital camera. By photographic images, using points pixel coordinates and the basic principles of photogrammetry (Obiralov, Limonov, \& Gavrilova, 2004), the girder position in space was determined before and after the action on it of external force.

It should be noted that in a modelled system with rigid support connections, the static girder deflection, determined by the expression (1), is $\delta^{C}{ }_{s t}=0.0004 m$, and dynamic $\delta^{C}{ }_{s t}=0.016 \mathrm{~m}$ (Iordanov et al., 2019).

To determine the girder deflection $X,(\mathrm{~m})$, the rock block with mass $m=0.2 \mathrm{~kg}$ from a height $H=0.3 \mathrm{~m}$ was dropped onto the girder, in case (a) in p. $D, B$ and $C$; in case (b) in p. $C$; in case (c) in p. $B$ (Fig. 5).
In case (a), there was an elastic impact, in case (b) and (c) - inelastic impact. The results of experiments with a yielding support, according to the modelling variants, are presented in Tables 4 and 5 .

Let us analyse the results of testing the experimental models with a yielding support with constant rigidity in the form of a spring. Figure 5 shows the graphs of changes in the value of deflection $X,(\mathrm{~m})$, amplitude $A,(\mathrm{~m})$ and frequency $k,(1 / \mathrm{s})$ of vibrations of a girder with a length $L$, (m) from the point of impact of the load with known mass.

It can be seen from the above dependences that when a load with mass $m=0.2 \mathrm{~kg}$ falls in p. $C$, the girder will have the greatest deflection, which is equal to $X=0.022 \mathrm{~m}$ (Fig. 3). Moreover, the share of the static deflection determined by (1), which is equal to $\delta_{s t}=0.012 \mathrm{~m}$, in total girder deflection after impact, when the load falls from a height of $H=0.3 \mathrm{~m}$, is about $50 \%$. 
Table 4. Experimental values of the girder deflection $X$, (m) and the yielding support rigidity $C_{\text {spr }},(\mathrm{kN} / \mathrm{m})$

\begin{tabular}{lccc}
\hline \multirow{2}{*}{ Criteria } & \multicolumn{3}{c}{ Variants of modelling } \\
\cline { 2 - 4 } & $\rho_{\text {b.d. }}=1980 \mathrm{~kg} / \mathrm{m}^{3}$ & $\rho_{\text {b.d. }}=1840 \mathrm{~kg} / \mathrm{m}^{3}$ & $\rho_{\text {b.d. }}=1680 \mathrm{~kg} / \mathrm{m}^{3}$ \\
\hline Deflection value $X,(\mathrm{~m})$ & 0.0014 & 0.005 & 0.0068 \\
Yielding support rigidity $C_{p},(\mathrm{kN} / \mathrm{m})$ & 11.2 & 3.1 & 2.3 \\
\hline
\end{tabular}

Table 5. Experimental values of the girder deflection $X,(\mathrm{~m})$ and the filling mass rigidity $C_{\text {spr }},(\mathrm{kN} / \mathrm{m})$

\begin{tabular}{lccccccccc}
\hline \multirow{2}{*}{ Criteria } & \multicolumn{10}{c}{ Variants of modelling } \\
\cline { 2 - 11 } & 1 & 2 & 3 & 4 & 5 & 6 & 7 & 8 & 9 \\
\hline Deflection value $X,(\mathrm{~m})$ & 0.0024 & - & 0.0015 & 0.0018 & 0.002 & 0.0026 & 0.003 & 0.0042 & 0.001 \\
Filling mass rigidity $C_{s p r},(\mathrm{kN} / \mathrm{m})$ & 6.5 & - & 10.4 & 8.7 & 7.8 & 6.0 & 5.2 & 3.7 & 15.6 \\
\hline
\end{tabular}

With such an interaction of a girder with a yielding support - spring, under the action of dynamic loads, when the rock block falls onto the free end of the supportable structure, the amplitude of vibrations increases, and the frequency, on the contrary, decreases (Fig. 5).

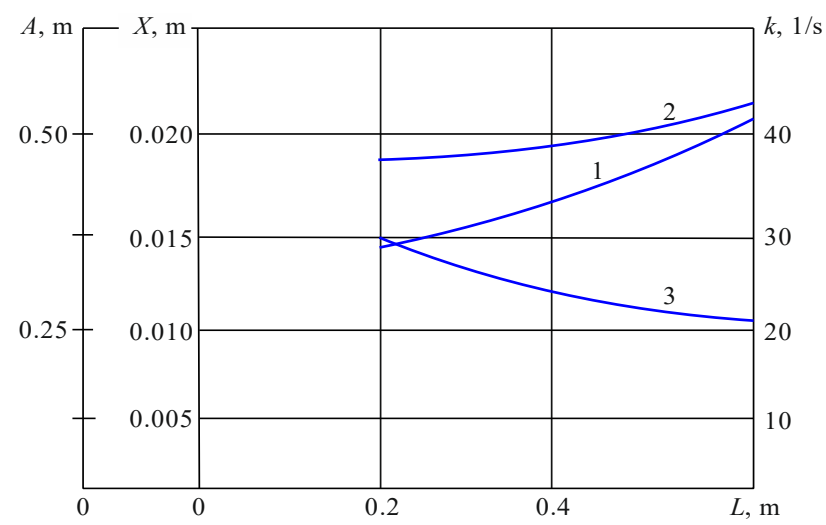

Figure 5. Graphs of changes in the value of deflection $X,(m)$, amplitude $A(m)$ and frequency of vibrations $k,(1 / \mathrm{s})$ of a girder in the modelled system, taking into account the point of impact: mass of a load $m=0.2 \mathrm{~kg}$, height of falling $\mathrm{H}=0.3 \mathrm{~m}, \mathrm{~L}_{\text {gir }}-$ length of a girder, $(m): 1-x,(m) ; 2-a,(m) ; 3-k,(1 / s)$

Figure 6 shows the graphs of changes in the cycle of vibration $T$, (s), quality factor $D$ of the considered deformable system and damping coefficient $\xi$, when a load with mass $m=0.2 \mathrm{~kg}$ falls onto a girder with a length $L$, $(\mathrm{m})$, taking into account the point of impact.

It can be seen from the above dependences that when a load falls onto the free end of the girder, the cycle of vibration $T$, (s) of a girder and damping coefficient $\xi$ increase, and the quality factor $D$, on the contrary, decreases. The set patterns indicate the damping of vibrations in the system. This process confirms the growth of the damping coefficient $\xi$, with account of the point where the load falls onto the girder (from p. $D$ to p. C), which is increases from $\xi=0.0065$ to $\xi=0.0083$, i.e. by $25 \%$ (Fig. 6).

Figure 7 shows the graphs of changes in the value of the phase shift in time $\tan \varphi$, the duration of the impact $t_{\text {imp }}$, (s) and the instantaneous power $N,(\mathrm{~W})$, developed to compress the spring from falling a load with known mass onto a girder with a length $L_{\text {gir }},(\mathrm{m})$, with account of point of impact. It can be seen from the above dependences (Fig. 6), that with an increase in time of impact $t_{i m p}$, (s), when the girder displacement $X,(\mathrm{~m})$ increases, the phase shift in time $\tan \varphi$ and the value of instantaneous power $N$, (W), developed for moving the girder, increase.

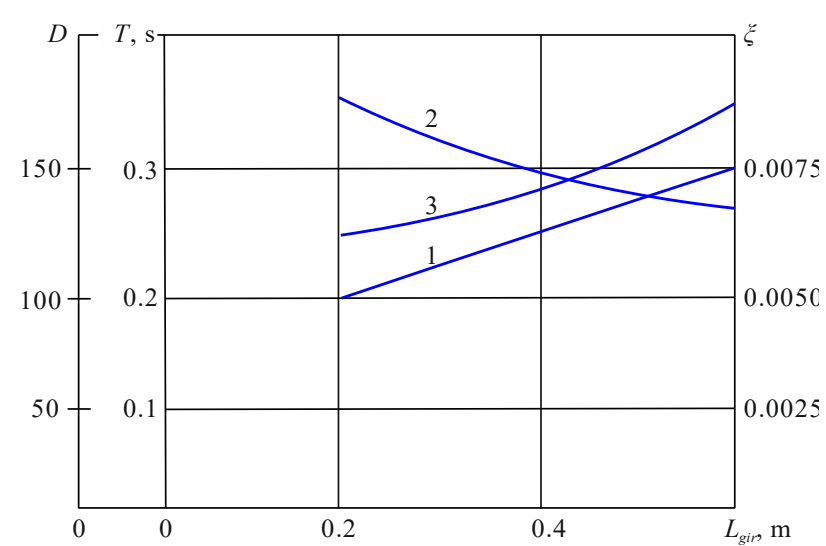

Figure 6. Graphs of changes in the cycle of vibration T, (s), quality factor $D$ of the considered system and damping coefficient $\xi$, when a load with mass $\mathrm{m}$, (kg) falls onto a girder with a length $L_{g i r},(m)$, taking into account the point of impact: $1-T,(s) ; 2-D ; 3-\xi$; $m=0.2 \mathrm{~kg}$

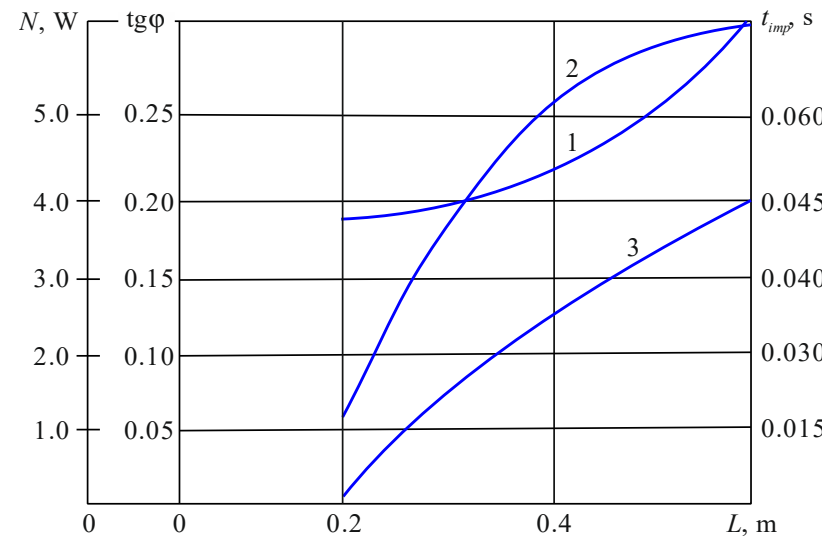

Figure 7. Graphs of changes in the value of the phase shift in time tan $\varphi$, duration of the impact $t_{i m p}$, (s) and instantaneous power $N,(W)$, developed for compressing the spring from falling the load with mass $m=0.2 \mathrm{~kg}$ onto the girder with a length $L$ gir, $(\mathrm{m})$, taking into account the point of impact: $1-\tan \varphi$; 2-timp, (s); 3-N, (W)

As a result of such work, for a certain period of time equal to $\Delta t=t_{i m p}+t_{s p r}$, (s), the compression of the spring occurs. Obviously, the greater the duration of the impact $t_{i m p}$, (s) and the value of the phase shift in time $\tan \varphi$, with account of the point of the rock block impact with the girder, relative to the yielding support, the greater the value of instantaneous power, which is necessary to compress the spring (Fig. 7). 
At the next laboratory research stage, let us replace the spring with a yielding support from crushed rock with different granulometric composition and consider the research results obtained.

Figure 8 shows the graphs of changes in the value of the girder deflection $X,(\mathrm{~m})$ from the yielding support rigidity $C_{s p r},(\mathrm{kN} / \mathrm{m})$, with account of its bulk density $\rho_{\text {b.d. }},\left(\mathrm{kg} / \mathrm{m}^{3}\right)$ and void ratio $M,(\%)$.

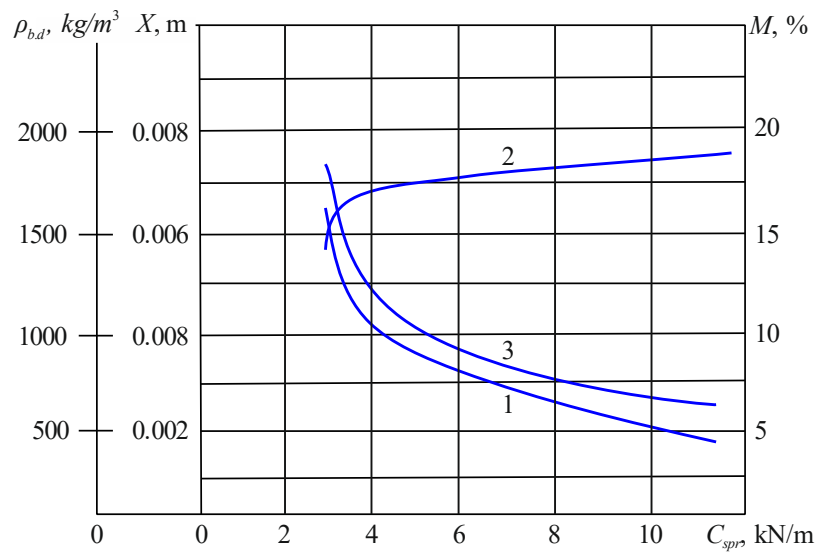

Figure 8. Graphs of changes in the value of the girder deflection $X,(m)$ from the yielding support rigidity $C_{s p r}$, $(\mathrm{kN} / \mathrm{m})$, with account of its bulk density $\rho_{\text {b.d. }},\left(\mathrm{kg} / \mathrm{m}^{3}\right)$ and void ratio $M,(\%): 1-X,(\mathrm{~m}) ; 2-\rho_{\text {b.d. }},\left(\mathrm{kg} / \mathrm{m}^{3}\right)$; $3-M,(\%)$

A number of phenomena follow from the above dependences, that with an increase in yielding support rigidity $C_{s p r},(\mathrm{kN} / \mathrm{m})$, the bulk density $\rho_{\text {b.d. }},\left(\mathrm{kg} / \mathrm{m}^{3}\right)$ increases, and void ratio $M,(\%)$ - decreases (Fig. 8).

As a result of falling the rock block with a mass of $m=0.2 \mathrm{~kg}$ from a height of $H=0.3 \mathrm{~m}$, the deflection of the girder $X,(\mathrm{~m})$ decreases with increasing the yielding support rigidity $C_{s p r},(\mathrm{kN} / \mathrm{m})$. The maximum girder deflection, equal to $X=0.0068 \mathrm{~m}$ is noted at the minimum rigidity of the yielding support, when $C_{s p r}=2.3 \mathrm{kN} / \mathrm{m}$. The minimum deflection of the girder, equal to $X=0.0014 \mathrm{~m}$, was recorded when the yielding support rigidity corresponded to $C_{s p r}=11.2 \mathrm{kN} / \mathrm{m}$. With that, the share of static deflection in the total girder deflection is $80-85 \%$.

Figure 9 shows the graphs of changes in the value of maximum yielding support compression $\Delta x,(\mathrm{~m})$, when falling the rock block onto the girder, with possible deviation of the girder from the equilibrium position $a,(\mathrm{~m})$, the dissipation factor $\psi$ and damping coefficient $\xi$, from the yielding support rigidity $C_{s p r},(\mathrm{kN} / \mathrm{m})$.

A phenomenon follows from the obtained dependences, that with account of a change in the yielding support rigidity, the value of its maximum compression is changed and, at $C_{s p r}=11.2 \mathrm{kN} / \mathrm{m}$ it takes the minimum values of $\Delta x=0.0004 \mathrm{~m}$. Then, as the rigidity of the support decreases to a value equal to $C_{s p r}=2.3 \mathrm{kN} / \mathrm{m}$, the value of $\Delta x,(\mathrm{~m})$, increases to $\Delta x=0.014 \mathrm{~m}$, i.g. by 3.5 times (Fig. 8). With that, the value of the maximum girder deviation from the equilibrium position $a,(\mathrm{~m})$ is changed. Moreover, with an increase in the rigidity of the yielding support from $C_{s p r}=2.3 \mathrm{kN} / \mathrm{m}$ to $C_{s p r}=11.2 \mathrm{kN} / \mathrm{m}$, that is by 4.8 times, the value $a,(\mathrm{~m})$, decreases, respectively, from $a=0.008 \mathrm{~m}$ to $a=0.0039 \mathrm{~m}$, i.g. by 2 times.

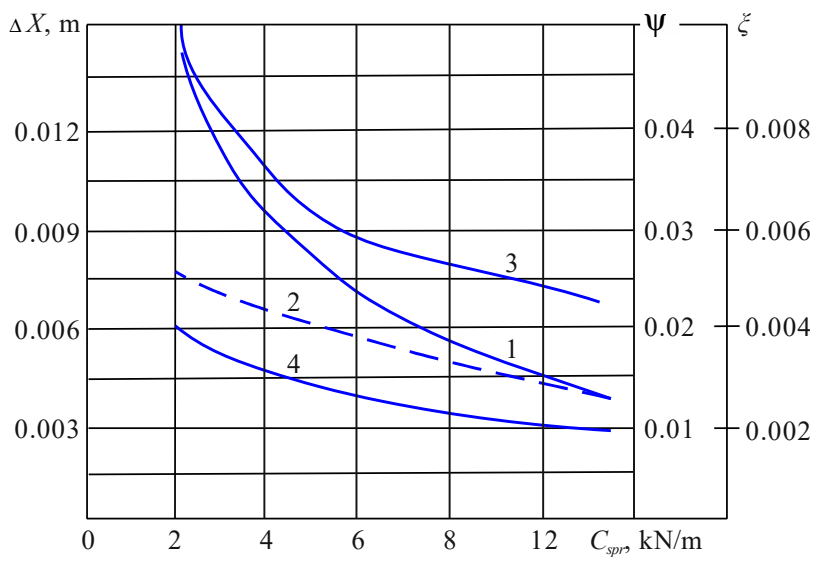

Figure 9. Graphs of changes in the value of maximum yielding support compression $\triangle X,(m)$, upon which the girder is backed, the possible deviation of the girder from the equilibrium position $a,(m)$, dissipation factor $\psi$ and damping coefficient $\xi$ from the support rigidity $C_{s p r},(\mathrm{kN} / \mathrm{m})$, when falling the load of $m=0.2 \mathrm{~kg}$, from a height of $\mathrm{H}=0.3 \mathrm{~m}: 1-\Delta X,(\mathrm{~m})$; $2-a,(m) ; 3-\psi ; 4-\xi$

It was noted that with an increase in the rigidity of the yielding support, the values of the dissipation factor $\psi$ and damping coefficient $\xi$, decrease (Fig. 9).

It has been found that the changes in the value of maximum compression of the yielding support $\Delta X,(\mathrm{~m})$ and possible girder deviation from the equilibrium position $a,(\mathrm{~m})$, with account of changing the rigidity of the support $C_{s p r},(\mathrm{kN} / \mathrm{m})$ (Fig. 8, dependence 1 and 2). It has been determined experimentally that when the rigidity of the yielding support $C_{s p r} \geq 10.2 \mathrm{kN} / \mathrm{m}$, the value of its maximum compression $\Delta X,(\mathrm{~m})$ is equal to the value of the possible girder deviation from the equilibrium position, in other words, when, $a \approx \Delta x,(\mathrm{~m})$, as a result of the dynamic load on the girder, the girder is destroyed and the equilibrium of the modelled system is disturbed. In case when $C_{s p r}<10.2 \mathrm{kN} / \mathrm{m}$ and $a<<x$, (m), the modelled system is in a state of equilibrium, the integrity of the girder is preserved.

Figure 10 shows the graphs of changes in the duration of the impact $t_{i m p}$, (s), the period of time during which the girder displacement reaches the maximum values $\Delta t$, (s) and the value of the phase shift in time $\tan \varphi$, from the rigidity of the yielding support $C_{s p r},(\mathrm{kN} / \mathrm{m})$.

It has been set that with an increase in the rigidity of the yielding support, the duration of the impact $t_{i m p}$, (s) and the period of time during which the girder displacement reaches the maximum values $\Delta t$, (s), decrease. As a result of such a girder interaction with a yielding support, after the end of the external force action, the movement of the girder continues due to a phase shift in time. Moreover, with an increase in the support rigidity, the phase shift $\tan \varphi$ decreases (Fig. 10).

It can be seen from the above dependences, that with the rigidity of the yielding support $C_{s p r}=2.3 \mathrm{kN} / \mathrm{m}$, the duration of the impact $t_{i m p}=0.041 \mathrm{~s}$, and the period of time during which the girder displacement reaches the maximum values $\Delta t=0.044 \mathrm{~s}$. The difference between these values is $0.003 \mathrm{~s}$. In the case when the rigidity of the yielding support is $C_{s p r}=3.1 \mathrm{kN} / \mathrm{m}$, the difference between the studied values is $0.002 \mathrm{~s}$. 


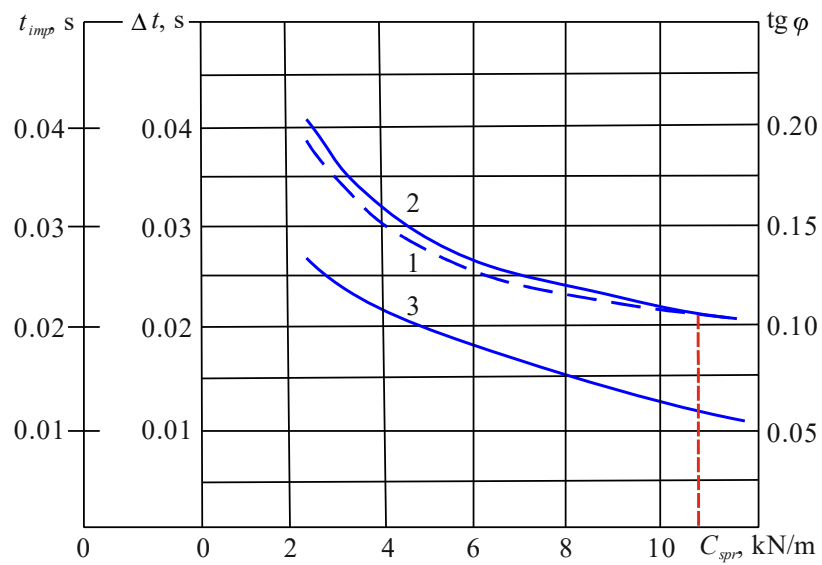

Figure 10. Graphs of changes in the duration of the impact timp, (s), the period of time $\Delta t$, (s) and the value of a phase shift in time tan $\varphi$ from the rigidity of the yielding support $C_{s p r},(\mathrm{kN} / \mathrm{m}): 1-t_{i m p},(\mathrm{~s}) ; 2-\Delta t$, (s); $3-\tan \varphi$

With the rigidity of the yielding support $C_{s p r}=11.2 \mathrm{kN} / \mathrm{m}, t_{i m p}=\Delta t$, (s) (Fig. 10, dependence 1 and 2). It is obvious that under the action of dynamic loads, in the case $t_{i m p}=\Delta t$, (s) and $a \approx \Delta t$, (s), the destruction of the girder in the modelled system occurs (Fig. 9 and 10, dependences 1 and 2).

At the final stage of research, let us replace the yielding support with a filling mass, which is located as shown in Figure 4c. Let us analyse the research results.

Figure 11 shows a graph of changes in the void ratio of the filling mass $M,(\%)$ and the value of bulk density $\rho_{\text {b.d. }},\left(\mathrm{kg} / \mathrm{m}^{3}\right)$ from the rigidity $C_{s p r},(\mathrm{kN} / \mathrm{m})$.

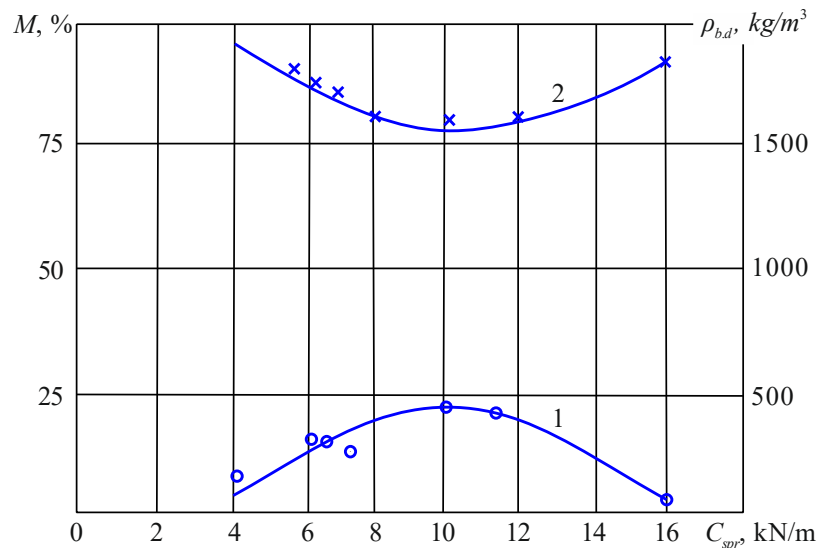

Figure 11. Changing the void ratio $M$, (\%) of filling mass and its bulk density $\rho_{\text {b.d. }},\left(\mathrm{kg} / \mathrm{m}^{3}\right)$ from the rigidity $C_{s p r}$, $(\mathrm{kN} / \mathrm{m}): 1-M,(\%) ; 2-\rho_{\text {b.d. }}, \mathrm{kg} / \mathrm{m}^{3} ; \times, o-$ experimental values

When performing experimental research, it has been determined that under the force impact of a falling load with known mass onto a girder, granulometric composition influences on the void ratio $M,(\%)$ and filling mass rigidity $C_{s p r},(\mathrm{kN} / \mathrm{m})$. It was recorded that the presence in the filling mass of $100 \%$ particles with sizes $d<1.0 \mathrm{~mm}$ ensures the rigidity of the yielding support $C=15.6 \mathrm{kN} / \mathrm{m}$, with void ratio $M=6 \%$. The bulk density value in this case corresponds to $\rho_{b . d}=1980 \mathrm{~kg} / \mathrm{m}^{3}$ (Fig. 11). The addition of $20 \%$ fine fractions $d<1.0 \mathrm{~mm}$ and $40 \%$ of fractions $d=1.0$ to $40.0 \%$ of fractions $d=2.0 \mathrm{~mm}$, provides the minimum rigidity of the filling mass $C_{s p r}=3.7 \mathrm{kN} / \mathrm{m}$ with void ratio $M=10 \%$. The presence in the yielding support of $100 \%$ particles with size $d=4.0 \mathrm{~mm}$, ensures the maximum void ratio of the filling mass $M=20 \%$ with rigidity $C_{s p r}=10.4 \mathrm{kN} / \mathrm{m}$ and bulk density $\rho_{\text {b.d. }}=1670 \mathrm{~kg} / \mathrm{m}^{3}$ (Fig. 10). In this case, after the force impact of the falling load onto the girder, the integrity of the girder is preserved.

Figure 12 shows the graphs of changes in the value of the girder displacement $X,(\mathrm{~m})$ and phase shift in time $\tan \varphi$ from the filling mass rigidity.

It can be seen from the above dependences, that with an increase in the filling mass rigidity, the values of girder displacement $X,(\mathrm{~m})$ and the phase shift in time $\tan \varphi$, decrease (Fig. 12).

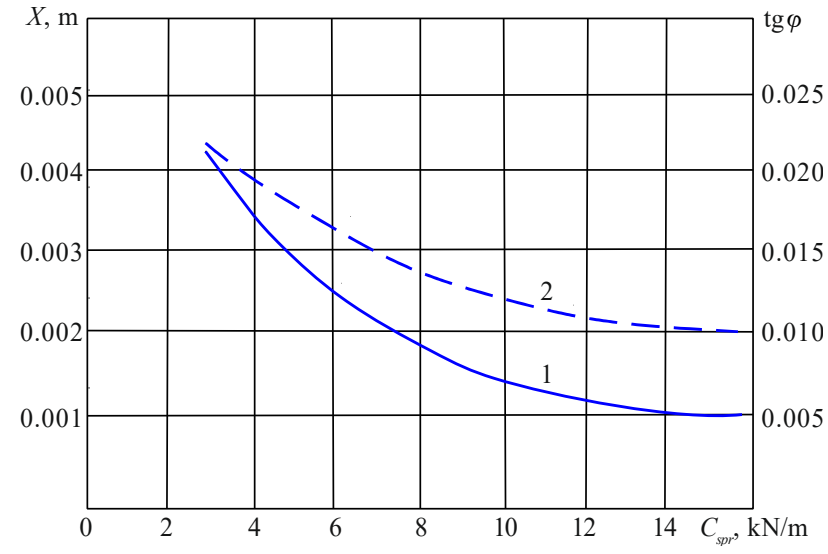

Figure 12. Graphs of changes in the value of girder displacement $X,(m)$ and phase shift in time tan $\varphi$ from the filling mass rigidity $C_{s p r},(\mathrm{kN} / \mathrm{m}): 1-X,(\mathrm{~m}) ; 2-\tan \varphi$

In case, when the rigidity of the filling mass is minimum, the value of instantaneous compression is $\Delta X>a_{T}$ (Fig. 13). With an increase in the rigidity of the filling mass, the difference between the studied values is reduced and, at $C_{s p r} \geq 12.7 \mathrm{kN} / \mathrm{m}$ we obtain $\Delta X \approx a$ which indicates the destruction of the girder (Fig. 13).

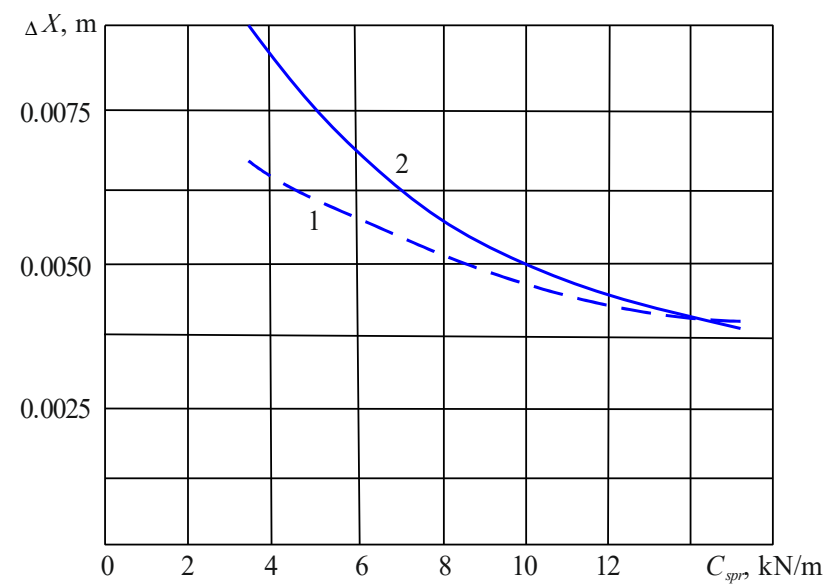

Figure 13. Graphs of changes in the value of maximum filling mass compression $\triangle X,(m)$ and possible girder deviation $a,(m)$, in case of falling the load with a known mass from the filling mass rigidity $C_{\text {spr }}$, $(k N / m): 1-a,(m) ; 2-\Delta X,(m)$ 
Thus, as a result of performed research of the stability of the coal seam roof rocks, presented in the form of a girder with a yielding support, it has been found that under impact loads, in order to determine the parameters of side rocks stability, in addition to bending deformations, it is necessary to consider the point of mutual impacting of the falling load with the girder, relative to the yielding support. In addition, if there is a yielding support, with account of the materials inhomogeneity of the girder and the yielding support, the value of the external force acting on the girder, the girder deformation will lag behind the displacement in time by the value of phase shift, which depends on the physical-mechanical properties of the girder and the yielding support, as well as the girder mass. Based on this, the girder deformation caused by the corresponding displacements reaches its greatest value not simultaneously with the end of the external force action on the girder, but through a certain value of $\tan \varphi$, which depends on the yielding support rigidity.

The phenomenon has been proved that the stability of the coal seam roof as a deformable system, having yielding support connections, depends on the value of the external force acting on the girder and the yielding support rigidity $C_{s p r},(\mathrm{kN} / \mathrm{m})$, onto which the girder is backed. With an inelastic impact, an increase in the yielding support rigidity has been recorded, while decreasing the value of maximum girder deflection. At the same time, the system itself absorbs deformation energy to the maximum, which increases the probability of the side rocks destruction and their collapse into mine working.

It has been set experimentally that in a modelled deformable system, like a girder with a yielding support connections, after a force action from a falling rock, the value of maximum displacement depends on the static compression of the yielding support and the deviation of the centre of masses from the equilibrium position upon impact.

The destruction of the girder, and, consequently, of the roof rocks, under the action of dynamic loads and their collapse into mine working, occurs under conditions that the void ratio of the yielding support, designed to bear the rocks of the coal seam roof behind the stope face and with an increase in its bulk density, is greater than $M>20 \%$ or less than $M \leq 6 \%$. The stability of the modelled system, in which the roof rocks are presented in the form of a girder, which is backed on a yielding support, is provided under conditions when its void ratio is in the range of $M=(7-20) \%$, with a decrease in its bulk density. When determining the displacements in such a system, in addition to girder bending deformations, it is necessary to consider the yield value of protecting structures, but taking into account the substantiated granulometric composition of crushed rock in a yielding support or filling mass.

For all that, as a result of changing the length of the girder spans, its flexural rigidity changes, which means that the influence of the yield of the same supports is different. As a consequence of this, that this support is rigid or yielding can only be said in relation to the physical-geometrical characteristics of a particular system. However, even this assessment may change, depending on the type of external load and the place of its application.

\section{CONCLUSIONS}

Based on theoretical and experimental research, the phenomena have been determined of the coal seam roof stability in the area adjacent to the longwall face and behind the stope face, as well as the influence of the yielding support on the value of deformations of the side rocks bending caused by dynamic loads. The effective supporting of the undermined rock stratum in the working part of the stope face and behind the face is achieved by creating a technology that provides for the formation, when mining coal, of constant-width outcropping and placing in the mined-out space of yielding protecting structures - supports or filling mass from material with a certain granulometric composition, with a minimum lagging behind the stope face. Using the research results to solve the problem of stability of the local preparatory mine workings, when the stratified drift is located between the whole coal and the filling mass, with a distance of 3-4 $\mathrm{m}$ between them, makes it possible to substantiate the stability of the haulage entries when mining the steeply inclined and steep seams. It also increases the measures effectiveness on the protection of miners' labour in deep coal mines.

\section{ACKNOWLEDGEMENTS}

The authors express their gratitude to the staff of the Mining Department of Donetsk National Technical University and Krasnoarmiisk (Pokrovsk) Industrial Institute for assistance in conducting the laboratory research.

\section{REFERENCES}

Akimov, V.A. (2010). Teoreticheskaya mekhanika. Dinamika material'noy tochki. Minsk, Belorussiya: Novoye znaniye.

Baruh, H. (2015) Applied dynamics. London, United Kingdom: CRC Press, Taylor \& Francis Group. https://doi.org/10.1201/b17897

Belyayev, N.M. (1985). Soprotivlenie materialov. Moskva, Rossiya: Nauka.

Bondarenko, V., Kovalevs'ka, I., \& Ganushevych, K. (2014). Progressive technologies of coal, coalbed methane, and ores mining. London, United Kingdom: CRC Press, Taylor \& Francis Group. https://doi.org/10.1201/b17547

Borisov, A.A. (1980). Mekhanika gornykh porod i massivov. Moskva, Rossiya: Nedra.

Borshch-Komponiyets, V.I. (2013). Prakticheskaya mekhanika gornykh porod. Moskva, Rossiya: Izdatel'stvo "Gornaya Kniga".

Bottega, W.J. (2006). Engineering vibrations. London, United Kingdom: CRC Press, Taylor \& Francis Group. https://doi.org/10.1201/9781420020090

Bridzhmen, P.V. (2001). Analiz razmernostey. Izhevsk, Rossiya: NITS "Regulyarnaya i khaoticheskaya dinamika".

DSTU EN196-1:2007. (2007). Natsional'nyy standart Ukrayiny. Metody vyprobuvannya tsementu. Chastyna 1. Vyznachennya mitsnosti. Kyiv, Ukraina: Minbud Ukrainy.

Ebrahimi, F. (2011). Advances in vibration analysis research. London, United Kingdom: IntechOpen Limited. https://doi.org/10.5772/639

Ginsberg, I. (2008). Engineering dynamics. Cambridge, United Kingdom: Cambridge University Press. https://doi.org/10.1017/cbo9780511805899 
Gusev, A.F., \& Novoselova, M.V. (2017). Prikladnaya teoriya kolebaniy. Tver', Rossiya: Tverskoy gosudarstvennyy universitet.

Havrysh, M.M., \& Hrebonkina, S.S. (2004). Mekhanika hirskykh porid. Donetsk, Ukraina: DonNTU.

Iordanov, I., Simonova, Y., Petrenko, A., Polozhiy, A., Podkopaiev, S., Dovgal, V., \& Korol, A. (2019). Research on models of stability of rocks of the roof of coal stray during dynamic loads. Bulletin of the National Technical University "KhPI". Series: New Solutions in Modern Technologies, $0(5(1330)), 17-26$.

https://doi.org/10.20998/2413-4295.2019.05.03

Kil'chevskiy, N.A. (1969). Teoriya soudareniy tverdykh tel. Kiev, Ukraina: Naukova dumka.

Khalymendyk, I., \& Baryshnikov, A. (2018). The mechanism of roadway deformation in conditions of laminated rocks. Journal of Sustainable Mining, 17(2), 41-47. https://doi.org/10.1016/j.jsm.2018.03.004

Kleeppner, D., \& Kolenkow, R. (2014) An introduction to mechanics. United Kingdom: Cambridge University Press. https://doi.org/10.1017/cbo9781139013963

Kovaleva, N.V., Rutman, Yu.L., \& Davydova, G.V. (2013) Opredeleniye optimal'nykh parametrov dempfirovaniya $\mathrm{v}$ sistemakh seysmoizolyatsii. Inzhenerno-Stroitel'nyy Zhurnal. Magazine of Civil Engineering, (5), 107-115.

Kutateladze, S.S. (1982). Analiz podobiya i fizicheskiye modeli. Novosibirsk, Rossiya: Nauka.

Mikhlin, Y.V., \& Zhupiev, A.L. (1997). An application of the ince algebraization to the stability of non-linear normal vibration modes. International Journal of Non-Linear Mechanics, 32(2), 393-409. https://doi.org/10.1016/s0020-7462(96)00047-9

Nikolin, V.I., Podkopaev, S.V., Agafonov, A.V., \& Maleev, N.V. (2005). Snizhenie travmatizma ot proyavleniy gornogo davleniya. Donetsk, Ukraina: Nord-Press.

Obiralov, A.I., Limonov, A.N., \& Gavrilova, N.A. (2004). Fotogrammetriya. Moskva, Rossiya: Kolos S.
Pivnyak, G.G., Pilov, P.I., Bondarenko, V.I., Surgai, N.S., \& Tulub, S.B. (2005). Development of coal industry: The part of the power strategy in the Ukraine. Gornyi Zhurnal, (5), 14-17.

Rusakov, A.I. (2003). Korrektnyy raschet privedennykh mass pri udare. Vestnik RGUPS, (2), 134-137.

Shakirzyanov, R.A., \& Shakirzyanov, F.R. (2005). Dinamika $i$ ustoychivost' sooruzheniy. Kazan', Rossiya: Izdatel'stvo Kazanskogo gosudarstvennogo arhitekturno-stroitelnogo universiteta.

Shashenko, A.N., Pustovoytenko, V.P., \& Sdvizhkova, E.A. (2016). Geomekhanika. Kiev, Ukraina: Naukovyi druk.

Shashenko, A., Gapieiev, S., \& Solodyankin, A. (2009). Numerical simulation of the elastic-plastic state of rock mass around horizontal workings. Archives of Mining Sciences, 54(2), 341-348.

Strelkov, S.P. (2005). Vvedeniye $v$ teoriyu kolebaniy. SanktPeterburg, Rossiya: Izdatel'stvo "Lan"”.

Timoshenko, S.P., \& Gere, Dzh. (2002). Mekhanika materialov. Sankt-Peterburg, Rossiya: Izdatel'stvovo "Lan"”.

Tsigler, F. (2002) Mekhanika tverdykh tel i zhidkostey. Izhevsk, Rossiya: NITS "Regulyarnaya i khaoticheskaya mekhanika".

Viktorov, S.D., Iofis, M.A., \& Goncharov, S.A. (2005). Sdvizhenie i razrushenie gornyh porod. Moskva, Rossiya: Nauka.

Vodop'yanov, V.I., \& Belov, A.A. (2001). Issledovaniye dempfiruyushchikh svoystv materialov. Vollgograd, Rossiya: VolgGTU.

Yakobi, O. (1987). Praktika upravleniya gornym davleniem. Moskva, Rossiya: Nedra.

Zborshchik, M.P., \& Podkopayev, S.V. (1992). Mekhanizm povysheniya ustoychivosti krovli v lavakh pri primenenii zakladki vyrabotannogo prostranstva. Kiev, Ukraina: Ugol' Ukrainy.

Zhukov, V.Ye., Vystorop, V.V., \& Kolchin, A.M. (1984). Malootkhodnaya tekhnologiya dobychi uglya. Kiev, Ukraina: Tekhnika.

\section{ФЕНОМЕНИ СТІЙКОСТІ ПОКРІВЛІ ВУГІЛЬНОГО ПЛАСТА ІЗ ПІДДАТЛИВОЮ ОПОРОЮ}

\section{С. Подкопаєв, В. Гого, І. Єфремов, О. Кипко, І. Іорданов, Ю. Сімонова}

Мета. Визначення умов і параметрів забезпечення стійкості покрівлі пласта з податливою опорою у привибійному просторі та позаду очисного вибою під впливом динамічних навантажень на основі аналітичних і лабораторних досліджень.

Методика. Для досягнення поставленої мети були виконані аналітичні дослідження із застосуванням основних положень теорії пружності й коливань, гіпотези балок і шарнірно-блокового зсування породної товщі, що розшаровується, а так само лабораторні дослідження моделей з еквівалентних матеріалів, в яких покрівля вугільного пласта представлена у вигляді балки, що має податливу опору змінної жорсткості із закладного матеріалу при динамічному навантаженні.

Результати. В результаті виконаних досліджень визначено феномен, що умовою стійкості покрівлі вугільного пласта, $\epsilon$ геометричний параметр, що відображає переміщення балки з піддатливою опорою, при силовому впливі падаючого вантажу відомої маси і фізико-геометричні характеристики деформованої системи. Визначено, що в результаті зміни довжини прольотів, відбувається зміна згинальної жорсткості балки, а значить вплив податливості одних і тих же опор, на стійкість покрівлі вугільного пласта різний. Встановлено величини і досліджено взаємозв'язок фізико-механічних характеристик закладного масиву як піддатливої опори.

Наукова новизна. Науково доведено, що напружено-деформований стан системи, в якій покрівля вугільного пласта досліджується як балка, залежить від фізико-геометричних характеристик системи, виду і місця докладання зовнішнього навантаження, коли визначено закон руху балки в часі.

Практична значимість. Ефективне підтримання підробленої породної товщі в робочій частині лави і позаду очисного забою, досягається за рахунок розміщення у виробленому просторі піддатливих опор або застосування закладки виробленого простору при веденні очисних робіт, що так само підвищує ефективність заходів 3 охорони праці гірників у вугільних шахтах.

Ключові слова: стійкість покрівлі, вугільний пласт, очисний вибій, феномен, напружено-деформований стан, теорія пружності і коливань, моделювання на еквівалентних матеріалах 


\title{
ФЕНОМЕНЫ УСТОЙЧИВОСТИ КРОВЛИ УГОЛЬНОГО ПЛАСТА С ПОДАТЛИВОЙ ОПОРОЙ
}

\author{
С. Подкопаев, В. Гого, И. Ефремов, А. Кипко, И. Иорданов, Ю. Симонова
}

Цель. Определение условий и параметров обеспечения устойчивости кровли пласта с податливой опорой в призабойном пространстве и позади очистного забоя под воздействием динамических нагрузок на основе аналитических и лабораторных исследований.

Методика. Для достижения поставленной цели были выполнены аналитические исследования с применением основных положений теории упругости и колебаний, гипотезы балок и шарнирно-блокового сдвижения расслоившейся породной толщи, а также лабораторные исследования моделей из эквивалентных материалов, в которых кровля угольного пласта представлена в виде балки, имеющей податливую опору переменной жесткости из закладочного материала при динамической нагрузке.

Результаты. В результате выполненных исследований определен феномен, что условием устойчивости кровли угольного пласта является геометрический параметр, отражающий перемещение балки с податливой опорой, при силовом воздействии падающего груза известной массы и физико-геометрические характеристики деформируемой системы. Определено, что в результате изменения длины пролетов, происходит изменение изгибной жесткости балки, а значит влияние податливости одних и тех же опор, на устойчивость кровли угольного пласта различно. Установлены величины и исследована взаимосвязь физико-механических характеристик закладочного массива как податливой опоры.

Научная новизна. Научно доказано, что напряженно-деформированное состояние системы, в которой кровля угольного пласта исследуется как балка, зависит от физико- геометрических характеристик системы, вида и места приложения внешней нагрузки, когда определен закон движения балки во времени.

Практическая значимость. Эффективное поддержание подработанной породной толщи в рабочей части лавы и позади очистного забоя, достигается за счет размещения в выработанном пространстве податливых опор или применения закладки выработанного пространства при ведении очистных работ, что так же повышает эффективность мероприятий по охране труда горнорабочих в угольных шахтах.

Ключевые слова: устойчивость кровля, угольный пласт, очистной забой, феномен, напряженнодеформированное состояние, теория упругости и колебаний, моделирование на эквивалентных материалах

\section{ARTICLE INFO}

Received: 21 June 2019

Accepted: 10 October 2019

Available online: 5 November 2019

\section{ABOUT AUTHORS}

Serhii Podkopaiev, Doctor of Technical Sciences, Professor of the Department of Mineral Deposits, Donetsk National Technical University, 2 Shybankova Ave., 85300, Pokrovsk, Ukraine. E-mail: serhii.podkopaiev@donntu.edu.ua

Volodymyr Gogo, Doctor of Technical Sciences, Professor of the Public Higher Education Institution, Industrial Institute of Donetsk National Technical University, 2 Shybankova Ave., 85300, Pokrovsk, Ukraine. E-mail: volodymyr.hoho@ii.donntu.edu.ua

Ihor Yefremov, Doctor of Technical Sciences, Professor of the Department of Mineral Deposits, Donetsk National Technical University, 2 Shybankova Ave., 85300, Pokrovsk, Ukraine. E-mail: ihor.yefremov@,donntu.edu.ua

Oleksandr Kipko, Doctor of Technical Sciences, Professor of the Department of Mineral Deposits, Donetsk National Technical University, 2 Shybankova Ave., 85300, Pokrovsk, Ukraine. E-mail: oleksander.kipko@donntu.edu.ua

Ihor Iordanov, Candidate of Technical Sciences, Chairman of the Board, LLC “TETZ-INVEST", 3 Oleksy Tykhoho St, 85103, Kostiantynivka, Ukraine. E-mail: gendir@eme.kiev.ua

Yuliia Simonova, PhD Student of the Department of Mineral Deposits, Donetsk National Technical University, 2 Shybankova Ave., 85300, Pokrovsk, Ukraine. E-mail: yuliia.simonova@donntu.edu.ua 